\title{
COVID-19 and the food system: setback or opportunity for gender equality?
}

\author{
Catherine Ragasa ${ }^{1}$ (D) Isabel Lambrecht ${ }^{2}$ \\ Received: 15 May 2020 / Accepted: 10 July 2020 / Published online: 14 July 2020 \\ (C) International Society for Plant Pathology and Springer Nature B.V. 2020
}

\begin{abstract}
Agriculture and the food sector are critical to food and nutrition security because they not only produce food but also contribute to economic empowerment by employing a large share of female and male workers, especially in developing countries. Food systems at all levels-globally, domestically, locally, and in the home - are expected to be highly affected by the COVID-19 crisis. Women and men work as food producers, processors, and traders and will likely be impacted differently. Shocks or crises can exacerbate or reduce gender gaps, and so can policy responses to mitigate the impact of these crises or shocks. We offer some perspectives and available country examples on how the COVID-19 crisis and responses to the crisis could be a setback or offer opportunities for gender equality in the food system.
\end{abstract}

Keywords COVID-19 $\cdot$ Food systems $\cdot$ Food supply chains $\cdot$ Gender $\cdot$ Women's empowerment

Agriculture and the food sector are critical to food and nutrition security. They not only produce food but also contribute to economic empowerment by employing large shares of workers, especially in developing countries. The COVID-19 crisis is expected to significantly affect food systems, through both disruptions caused by measures to contain the spread of the disease and the economic downturn it has caused. Food systems at all levels-globally, domestically, locally, and in the home-will feel the impact and need to adjust to new realities.

Both women and men work as food producers, processors, and traders; however, the different constraints they face lead to gender inequalities disfavoring women. Several inclusive agricultural value chain development and gender-sensitive agricultural programs demonstrate that these inequalities can

Catherine Ragasa

c.ragasa@cgiar.org

Isabel Lambrecht

i.lambrecht@cgiar.org

1 International Food Policy Research Institute (IFPRI), Washington, DC, USA

2 International Food Policy Research Institute (IFPRI), Yangon, Myanmar successfully be reduced (Johnson et al. 2016; Maertens and Verhofstadt 2013; Quisumbing et al. 2015).

Shocks or crises can exacerbate or reduce gender gaps, and so can policy responses to mitigate the impact of these crises or shocks. We offer some perspectives and available country examples on how the COVID-19 crisis and responses to the crisis could be a setback or offer opportunities for gender equality in the food system.

\section{Modern supply chains}

During the past three decades, modern supply chains for highvalue produce, such as horticulture products for high-income markets, have expanded rapidly across developing countries. They have not only changed the way food is produced and traded in developing countries but also affected the welfare of those engaged in the supply chains (Maertens and Swinnen 2012). Women constitute the majority of the labor force of many of those supply chains, for example in fresh flowers, fresh fruit, and vegetable processing and trading. Although exceptions exist, women's participation in these modern supply chains has often led to significant increases in women's income and empowerment.

The COVID-19 crisis has already severely affected global value chains and we can expect continued, long-term negative impacts on production and employment in these value chains. 
These impacts may result in a significant setback for women's income-generating opportunities and empowerment. Ethiopia's flower export sector, for example, is at risk of losing 150,000 employees, many of whom are women. ${ }^{1}$

To avoid this setback, the private sector and governments will need to find options to mitigate short- and long-term impacts. Businesses that are struggling to survive could innovate by diversifying products and shifting production to follow demand. For example, those in the flower sector could use their greenhouses, cold chains, and storage facilities for intensified production of vegetables with high demand locally or elsewhere; they could also venture from agroprocessing into scented sanitizers, perfumes, or other products. Some flower farmers in Kenya are using the Fairtrade Premium to keep workers employed, shifting some production temporarily to produce masks, and intensifying promotion of their product lines to consumers via online platforms. ${ }^{2}$ And many beer companies have responded to changing demand by shifting their production into hand sanitizers. ${ }^{3}$ Enterprises that remain in business must adjust practices and adopt precautionary measures to ensure buyer and consumer confidence in both worker and product safety. Enterprises already complying with high quality standards might more easily put in place additional employee health checks, protective gear provision, and sanitation measures.

Government can support such diversification and innovation through grants, temporary loan programs, and directed policies. Business support should encourage and explicitly target women-owned companies or those with large shares of women and youth workers. The government of Ethiopia, for example, removed the restriction on the floor price for flower exports to keep companies in business and able to supply any available domestic and international demand for flowers. ${ }^{4}$ Proactively stimulating demand and expanding markets locally and regionally across borders could also protect livelihoods. Government, the private sector, and researchers can work together to provide timely and strategic global and domestic market intelligence to guide businesses and investors, with particular attention to those markets with strong multiplier effects on rural development and women and youth employment.

\footnotetext{
${ }^{1}$ https://www.reuters.com/article/us-health-coronavirus-africa-women/nobed-of-roses-east-africas-female-flower-workers-lose-jobs-as-coronavirushits-exports-idUSKCN21T0AW; https://allafrica.com/stories/202003240613. html

${ }^{2}$ https://www.fairtrade.org.uk/Media-Centre/Blog/2020/June/Why-Fairtradeis-vital-for-flower-producers-during-the-COVID-19-pandemic; https://www. fairtrade.org.uk/Media-Centre/News/May-2020/Flower-and-cottonproducers-fight-Covid-19-through-tailoring

${ }^{3}$ https://www.bloomberg.com/news/articles/2020-03-24/companies-revampto-make-hand-sanitizer-and-coronavirus-products

${ }^{4} \mathrm{https}$ ://ethiopianmonitor.com/2020/04/04/ethiopia-garners-1-8bln-fromexport-in-eight-months/
}

\section{Domestic and local supply chains}

The growing population's continued demand for food offers a great incentive for increased investments and production. Keeping food supply chains open and allowing agricultural inputs and services to move freely during the crisis are key. Global food supply chain disruptions for major food producers and exporters, coupled with trade restrictions and border closures, provide opportunities to develop domestic and local food systems, especially for poor agricultural-based countries that rely heavily on imported foods. Implementation of input packages and short-term loan programs should begin immediately in order to support smallscale producers, processors, and traders. In past emergency and rebuilding programs, intensified seed multiplication and distribution have been particularly crucial for food production and income generation. Providing small packages of seeds and fertilizer has also proven effective in reaching and benefitting more women producers. ${ }^{5}$ The COVID-19 crisis has already reincentivized several governments to encourage homestead production, urban farming, and seed production, and to set up agriculture-oriented labor-intensive public work programs. In Myanmar, government programs use social media, demonstration plots, and distribution of vegetable seed kits to actively encourage homestead food production. ${ }^{6}$

Returning migrants and laid-off workers could become precious additions to the labor force, compensating for shortages of the labor necessary to intensify production of high-demand foods. These workers could be of particular use to womenheaded households that rely heavily on hired labor. In Nepal, some local governments have already begun developing specific guidelines for maximizing land use and protecting land rights of women and vulnerable groups. ${ }^{7}$ Such guidance could be scaled up and rolled out within the country or adopted by other countries.

Women-managed enterprises are generally constrained by lack of access to finance and assets and by entrenched gender norms (Quisumbing et al. 2014). Because of these constraints, intensified support for local food production does not automatically reach and benefit women without explicitly targeting them. For example, Myanmar increased loans to farmers, at lower interest rates, but women are less likely to obtain such loans as they are unlikely to be listed as the owner on the required land certificate (if any). ${ }^{8}$

\footnotetext{
${ }^{5} \mathrm{https} / / /$ www.care.org/sites/default/files/documents/covid_food_security and_gender_equality.pdf

${ }^{6}$ https://www.globalnewlightofmyanmar.com/koica-supports-210000-usdworth-of-vegetable-seed-kits-and-covid-19-healthcare-materials-to-moali/

${ }^{7}$ https://www.iied.org/curbing-impacts-covid-19-nepals-small-scale-farmersseizing-opportunities-for-food-system-reform

${ }^{8} \mathrm{https}: / / \mathrm{www}$. lincolnmyanmar.com/wp-content/uploads/2020/05/Monsoonagricultural-loans.pdf
} 
Several women's organizations, such as the Self-Employed Women's Association (SEWA) in India, have been actively leading crisis response and livelihood rebuilding programs, such as helping and organizing their women members to sell their vegetables. Agri-ambulances initiated by cooperatives in Nepal coordinate pick-up and mobile delivery of vegetable produce, which benefits many women farmers. ${ }^{9}$ Nongovernmental organizations have continued or intensified programs, including those targeting women and vulnerable groups, by combining cash transfers or food aid with training and facilitating market access. ${ }^{10}$

Digital platforms - although popular for agricultural extension, marketing, logistics and for feedback loops and accountability mechanisms - create problems for women because of women's lower digital access and literacy. Digital literacy training can help women and men take full advantage of advanced ICT applications. The development community and researchers should continue to monitor and evaluate these initiatives in order to identify promising ones for broad implementation across regions and countries.

\section{Women and food markets}

Emergency and recovery programs need to protect informal food markets, which rely mostly on women workers and are a critical food source for most consumers in poor countries. Around the globe, violence and crimes against those working in the informal sector have increased, including against informal vendors trying to ensure their livelihoods amid the lockdowns, for example in Uganda ${ }^{11}$ and India. ${ }^{12}$ Instead of crackdowns, investments in public handwashing facilities and greater sanitation and safety measures in the marketplace could prove a more vital and sustainable response to such outbreaks and to the current pandemic. In Burkina Faso, one COVID-19 response program targets women entrepreneurs, with priority given to food traders and vendors (IFPRI 2020). In Nepal, some local governments have been instrumental in managing opportunistic behavior by traders, transportation service providers, or other actors that disadvantage vulnerable groups and poor women producers. Some local governments have fixed minimum prices of agricultural products and curtailed black marketing. ${ }^{13}$ Despite experiments by many governments on how to ensure the continued (though

\footnotetext{
${ }^{9}$ https:/www.heifer.org/blog/during-covid-19-lockdown-nepal-cooperativeconnects-farmers-and-customers-with-innovative-agri-ambulance-.html

${ }^{10} \mathrm{https}$ //www.care.org/sites/default/files/documents/covid_food_security_ and_gender_equality.pdf

${ }^{11} \mathrm{https}$ ://globalvoices.org/2020/03/28/market-mayhem-in-uganda-as-covid19-measures-upend-womens-lives/

12 https://www.nytimes.com/2020/03/30/world/asia/coronavirus-indialockdown.html

${ }^{13}$ https://www.iied.org/curbing-impacts-covid-19-nepals-small-scalefarmers-seizing-opportunities-for-food-system-reform
}

often partial) operations of markets, informal street vendors are often forgotten. ${ }^{14}$

\section{Gender and food systems in policy responses}

COVID-19 policy trackers show that fewer attention goes to the agricultural and food sectors than to other sectors and that agriculture ministries are conspicuously absent from national and subnational COVID-19 response committees. ${ }^{15}$ The trackers do not account for gender sensitivity, even within the few agricultural- and food sector-specific responses, but it is clear that very few countries or programs explicitly target or mention women or gender balance. Decision-making committees on how to optimize local resources may also be dominated by or even consist exclusively men, with the result that gender gaps in wages and other gender discrepancies are maintained. Not explicitly targeting women - who are not only agricultural workers, producers, and entrepreneurs but also generally responsible for household nutrition-would be a missed opportunity. Gender-disaggregated data and gender monitoring should be promoted in policy response tracking.

Social protection programs (mostly cash and food) are the top crisis response measures being implemented in numerous countries — with some attention to women (IFPRI 2020). ${ }^{16}$ Gender-targeted interventions typically focus on assuring adequate child feeding, nutrition, and reducing domestic violence, but not on supporting women's economic opportunities. In Myanmar, the COVID-19 Economic Relief Plan includes support for farmers, small agri-processors, seed farmers, and agri-businesses, but has no explicit gender targeting (Lambrecht et al. 2020). In countries such as Myanmar, where men are considered the household head and main income earners, women often miss out on relief packages, information, and technical support to farmers or entrepreneurs. Globally, such policies perpetuate gender norms around women's main roles as caretakers and in fulfilling household chores rather than as producers, workers, or entrepreneurs.

In Tajikistan, a government program allocates soft loans to companies that produce food and medical supplies, especially for women entrepreneurs (IFPRI 2020). In Ghana, the business component within the country's Coronavirus Alleviation Program encourages women-owned businesses and persons with disabilities to apply. Such programs offer a good start

\footnotetext{
$\overline{14}$ https://www.ifpri.org/blog/covid-19-lockdowns-threaten-africas-vitalinformal-urban-food-trade

15 https://www.ifpri.org/blog/ifpris-covid-19-policy-response-cpr-portalidentifying-trends-and-implications-food-systems

${ }^{16}$ For a gender-sensitive social protection program, see https://www.ifpri.org/ blog/why-gender-sensitive-social-protection-critical-covid-19-response-lowand-middle-income
} 
to targeting women in large national response programs, but enforcement and implementation should be regularly monitored.

\section{Keep a gender lens, and seek opportunities for sustained positive change}

Applying a gender lens in setting up measures that mitigate the impact of COVID-19 in food systems can aid in designing more appropriate and effective policy measures and avoid unintentional harm or aggravation of gender inequalities. Doing so effectively means including women as active decision makers, as beneficiaries, and in statistics through collection of sex-disaggregated data. Much of the COVID-19 gender research published thus far is based on extrapolation from past crises. More data are urgently needed to look at the shortand longer-term impacts through a gender lens to account for the social context that has changed because of COVID-19. Social and cultural structures change quickly in crisis contexts, providing opportunities to redefine gender norms and power relations. Good practices during this crisis that are documented and shared could help in harnessing sustained changes toward greater gender equality and evolving social norms.

\section{Compliance with ethical standards}

Conflict of interest The authors declare that they have no conflict of interest in writing this piece.

\section{References}

International Food Policy Research Institute. (2020). COVID-19 policy response (CPR) portal. Washington, DC: IFPRI. Retrieved June 21, 2020 from https://www.ifpri.org/project/covid-19-policy-responsecpr-portal.

Johnson, N. L., Kovarik, C., Meinzen-Dick, R., Njuki, J., \& Quisumbing, A. (2016). Gender, assets, and agricultural development: Lessons from eight projects. World Development, 83, 295-311.

Lambrecht, I. Mahrt, K., Ragasa, C., Wang, M., Win, H.E., and Win, K. Z. (2020). A gender-transformative response to COVID-19 in Myanmar. Myanmar SSP policy note 4. Washington, DC: International Food Policy Research Institute (IFPRI).

Maertens, M., \& Swinnen, J. (2012). Gender and modern supply chains in developing countries. The Journal of Development Studies, 48(10), $1412-1430$

Maertens, M., \& Verhofstadt, E. (2013). Horticultural exports, female wage employment and primary school enrolment: Theory and evidence from Senegal. Food Policy, 43, 118-131.
Quisumbing, A., Meinzen-Dick, R., Raney, T., Croppenstedt, A., Behrman, J., \& Peterman, A. (2014). Gender in agriculture and food security: Closing the knowledge gap. Berlin: Springer.

Quisumbing, A. R., Rubin, D., Manfre, C., Waithanji, E., van den Bold, M., Olney, D., Johnson, N., \& Meinzen-Dick, R. (2015). Gender, assets, and market-oriented agriculture: Learning from high-value crop and livestock projects in Africa and Asia. Agriculture and Human Values, 32, 705-725.

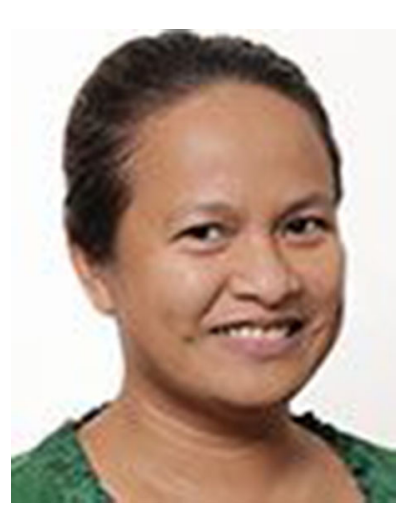

Catherine Ragasa is a Senior Research Fellow at the International Food Policy Research Institute (IFPRI) in Washington, DC. She is an agricultural economist whose research focuses on mixed quantitative and qualitative analysis of policies, institutions and technologies affecting innovation, productivity growth, and agricultural transformation. She received her $\mathrm{PhD}$ in Agricultural Economics from Michigan State University in 2008 and holds a Masters in Economics from the University of the Philippines-Diliman. Prior to IFPRI, she worked for five years (2004-2009) in the Agriculture and Rural Development Department at the World Bank, Washington, DC, working on agricultural innovation systems, value chains, and gender issues in agriculture and food systems.

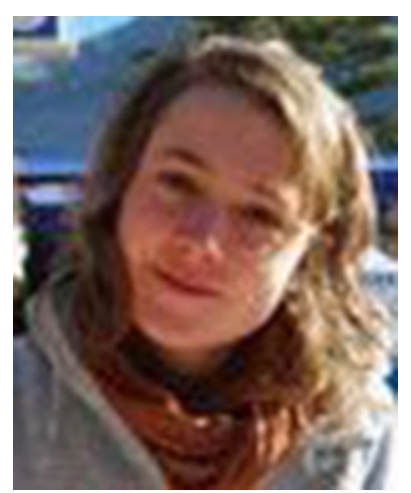

Isabel Lambrecht is a research fellow in the Development Strategy and Governance Division of IFPRI, based in Yangon, Myanmar, with a research focus and publication record on land tenure and women's empowerment. She employs both quantitative and qualitative research methods and is experienced in both data collection as well as econometric analysis of survey data. In 2014, she obtained her $\mathrm{PhD}$ in agricultural economics from KU Leuven University, Belgium, focusing on gender and integrated soil fertility management in Eastern DRC. After that, she was based in Ghana as an associate research fellow with IFPRI, conducting research on land tenure and women's empowerment. Since February 2018, she is a research fellow based in Myanmar focusing on gender inequality in rural Myanmar. 